\title{
Preparation of functional juice blends containing bioactive healthy compounds and antitumor effects
}

\author{
Mahmoud A. Elwakeel \\ Food Science Department, Faculty of Agriculture, Beni-Suef University, Beni-Suef62511, \\ Egypt \\ Email: mahmoud.elwakeel@agr.bsu.edu.eg
}

Received: November 15, 2020; Accepted: December 5, 2020 ; Available online December 20, 2020

\section{ABSTRACT}

Fruit juices are healthy drinks, where they contain vitamins, minerals and antioxidants that play an important role in preventing many diseases like cancer. To improve the nutritional value of juices, blending according to the kind of fruits used, four formulas of natural juices blends were prepared; blended formula 1(strawberry and banana), formulas 2 (carrot and sweet potato) formulas 3(banana, carrot and sweet potato) and formulas 4 (tiger nut). Their physic-chemical and sensory properties were evaluated. The total phenols, total flavonoids and antioxidant activity of fresh juices blends were evaluated using DPPH scavenging capacities method. The overall acceptability of blended juices of the four formulas showed the possibility to prepare blended juices characterized with good sensory and nutritional properties, besides having a source of natural antioxidants. The obtained five blended natural juices of strawberry, banana, carrot, sweet potato and tiger nut are good source of minerals and antioxidant activity of their vitamin $\mathrm{C}$, flavonoids and total phenolics contents. In the test of four formulas for the protective effect against human cell lines gave positive results. In conclusion, the results of the current study suggested that the prepared formulas are a good source of bioactive compounds such as phenolic and flavonoids with potentially high antioxidant activities that natural play a role as antitumor.

Kewword: Fruit juices, carrot, strawberry, tiger nut, banana, Physico-chemical, total phenols, total flavonoids, caner.

\section{INTRODUCTION}

Fruit Juices are a good source of vitamins, minerals and essential valuable bioactive compounds for human health. The health benefits associated with drinking natural fruit juices are related to their bioactive components such as essential vitamins, minerals and polyphenolic compounds. Therefore, fruit beverages are well known for their medicinal properties (Hădărugă, 2009; Wootton-Beard and Ryan, 2011). The blended juice is characterized with its improved aroma, taste and nutrients of the beverages (Deka and Sethi, 2001). This method is bright to improve the content of blending juices of minerals and vitamins according to the type of fruits used (Day et al., 2010). Furthermore, when blending juices, a new product with high health and nutritional properties can be formed.

Strawberry fruit has several phytochemical compounds such askatekin, acid elagiat, antosianin, kuaerferin and kaemferol. Antosianin is antioxidants able to avoid atherosclerosis through hamper aterogenesis process by oxidize the LDL (Buvé et al., 2018).

Carrot juice has vitamins, carotene and minerals (De Carvalho et al., 2007; Di Giacomo and Taglieri., 2009). Carotene is able to exhibit the free radical properties, and is effectiveness as a biological antioxidant (Filotheou et al., 2012).

Honey bees is characterized by its widely used for therapeutic effects and it has about 200 substances like fructose, glucose, fructo-oligosaccharides (Chow, 


\section{Mahmoud A. Elwakeel}

2002), many amino acids, vitamins, minerals and enzymes (White, 1979). Furthermore, Honey bees containing phenolics, peptides and organic acids compounds that represent important compounds in the treatment of many diseases for its antioxidant capacity.

Ginger and Cinnamon has been used as a spice. Ginger is characterized by its antimicrobial activity (Onyeagba et al., 2004). Ginger and cinnamon were used as a medicinal plant, where ginger was used for cramps, sprains, rheumatism, arthritis, muscular aches, pains, hypertension, sore throats, indigestion, helminthiasis, dementia, fever, infectious constipation, diseases and vomiting (Ali et al., 2008). Although, cinnamon has been working for stomachic and carminative aimed at gastrointestinal complaints (Teuscher, 2003).

Sweet potatoes are inordinate source of beta-carotene, that stretchesa powerful antioxidant. Beta-carotene is transformed to vitamin A in human body. Consumption foods prosperous in betacarotene reduce the risk of developing certain types of cancer, offer protection against asthma and heart disease, and delay aging and body degeneration.

Date juice concentrate (76\% TSS) is a good source of sugars (63\% reducing sugars, $67 \%$ total sugars,), tannins $(1.16 \%)$ and acidity (0.33\%) (Kulkarni et al., 2010).

Consumption of tiger nut now is steadily increased. Tiger nut is characterized by its protein content and fibre, which helps in body development and repair tissues. The fibre also helps in reducing cholesterol and body weight. There are some products that could be obtained from tiger nut, i.e tiger nut flour, "'Dakuwa", "kunu", and Tiger nut oil and some of them could be eaten as snack (Gambo and Da'u, 2014).

Bananas have several health benefits, i.e., lowering blood pressure, lowering the risks of cancer and reduce the risk of heart disease (Holmes, 2013).
Cocoa and its products, namely cocoa powder, dark chocolate and cocoa liquor, have been proven to suppress the development of atherosclerotic lesions (Kurosawaet et al., 2005), reduced platelet function (Murphy et al. 2003) and exerted hypoglycemic properties (Tomaru et al. 2007). Despite its abundance in bioactive compounds, numerous enriched cocoa products are a subject of scientific research, due to consumers' orientation towards functional products (BelščakCvitanović et al., 2012)

Natural fruit juices contain large amounts of high-value phytochemicals, making it ideal to be used in food and pharmaceutical products. Natural fruit juices such as Strawberry, Banana,Carrot, Sweet potato and Tiger nut containing phenolic compounds, dietary fiber, carotenoids, vitamin $\mathrm{C}$ and vitamin $\mathrm{E}$ (Ajila et al., 2007). Sultana et al. (2012) reported that polyphenolics from natural fruit juices exhibit an excellent antioxidant activity.

The antioxidant potentials of plant bioresources, mainly contributed by their bioactive compounds, have been closely linked to their ability to suppress growth of cancer cells, likely through decrease oxidative stress, which may play a role in the development and progression of cellular damages underlying cancerous growth. As such, it has been recommended that antioxidant supplementation may decrease cancer recurrence and mortalities (Fleischer et al., 2003).

The present study aimed to produce and evaluate juices blends characterized with its accepted sensory and healthy properties from some fruits and vegetables to be as a functional juice and to investigate the effect of these juices on breast cancer (MCF-7), liver cancer (HEPG-2), and colon cancer (HCT116) cancer cell lines.

\section{MATERIALS AND METHODS} Materials:

Strawberry, carrot, sweet potato and banana were obtained from local 


\section{Preparation of functional juice blends containing bioactive healthy compounds and antitumor effects}

market, Cairo, Egypt. Honey bees, ginger, vanilla, cinnamon and cacao powder were obtained from spice shop and super market, Cairo, Egypt.
Four juices Formula were prepared and their ingredients are shown in Table (1). This formula approved after sensory evaluation and this formula have highest ratio from pane lists.

Methods:

Table (1). Ingredients of the tested juice blends formula.

\begin{tabular}{|c|c|c|c|c|}
\hline Ingredients & Formula 1 & Formula 2 & Formula 3 & Formula 4 \\
\hline Strawberry & 60 & - & - & - \\
\hline Banana & 35 & - & 45 & - \\
\hline Carrot & - & 45 & 21 & - \\
\hline Sweet potato & - & 44 & 20 & 3 \\
\hline Ginger & - & 3 & - & 2 \\
\hline Cinnamon & - & 2 & - & - \\
\hline Coco powder & - & - & 8 & 6 \\
\hline Honey bees & 5 & 6 & 6 & 60 \\
\hline Tiger nut & - & - & - & 29 \\
\hline water & - & - & - & \\
\hline
\end{tabular}

\section{Physico-chemical analysis:}

Gross chemical of fruits and vegetables that used to prepare juice blends were determined, and available carbohydrates were determined by difference according to the methods of AOAC (1995).

Juice blends were evaluated as follows: Total Soluble Solids (TSS) were evaluated as Brix value using a hand Refractometer (ATAGO, Japan). Acidity was determined as percentage of citric acid according to the method of AOAC (1995). Brix/acid ratio was calculated for each sample. The $\mathrm{pH}$ value was evaluated using Hanna pH-meter HI 9021 m Germany. Vitamin $\mathrm{C}$ of prepared juice blends was evaluated using 2,6 di-chlorophenolindophenol (AOAC, 1995). Apparent viscosity was evaluated using Brookfield DV-III UITRA in centipoises (cP) unit according to the method of Ibarz et al. (1994). Color parameters $\left(L^{*}, a^{*}\right.$ and $\left.b^{*}\right)$ of juice blends were evaluated using Hunter, Lab Scan XE-Reston VA, USA. The instrument was standardized using white tile (LX No. 16379): $X=72.26, Y=$
81.94 and $\mathrm{Z}=88.14\left(\mathrm{~L}^{*}=92.46, \mathrm{a}^{*}=-\right.$ $\left.0.86, b^{*}=-0.16\right)$ as stated by Sapers and Douglas (1987).

The total phenolics content of juice blends were evaluated as gallic acid equivalent (mg GAE $\mathrm{g}^{-1}$ of dry weight) using the method of Folin-Ciocalteu30. Also, Flavonoids contents of juice blends were evaluated as catachine equivalents (mg CAT $\mathrm{g}^{-1}$ fruit on dry weight) using $\mathrm{AlCl}_{3}$ method (Lamaison et al., 1990).

Antioxidant activity of the prepared juices blends were evaluated using DPPH radical-scavenging assay and $\alpha$-carotenelinoleic acid bleaching assay as reported by Grzegorczyk et al. (2007) and Matthaus (2002), respectively.

\section{Sensory evaluation:}

Sensory evaluation of four blended juice samples was tested through taste, odor, color, mouth feel, appearance and overall acceptability as stated by Hussein and Shedeed (2011).

Antitumor activity:

Four juices formula were subjected to cytotoxic assessment on human tumour cell line. In this experiment Doxorubicin 
Mahmoud A. Elwakeel

was used as a positive control. The title extracts were dissolved in 20\% Dimethyl sulphoxide (DMSO) in concentration $1 \mathrm{mg} / \mathrm{ml}$. Serial dilutions were made attainment final concentration of the compounds to $12.5,25,50$ and $100 \mu \mathrm{g} / \mathrm{ml}$. The tumour cell lines were obtained frozen in liquid nitrogen $\left(-180^{\circ} \mathrm{C}\right)$ from the American Type Culture Collection (ATCC) was maintained at the National Cancer Institute, Cairo, Egypt, by serial subculturing. The antitumor activity was measured in vitro on human cancer cell line (MCF-7, HCT116 and HEPG2) using sulphorhodamine -B stain (SRB) assay applying the method of Skehan et al. (1990).

\section{Statistical analysis:}

Results were expressed as mean values and standard deviation of three (3) determinations. Data were analyzed using one-way analysis of variance (ANOVA) using Statistical Package for Social Science (SPSS) version 16.0 software 2010 to test the level of significance at 5\% probability $(\mathrm{P}<0.05)$. Duncan's New Multiple Range Test was used to separate the means where significant differences existed according to the method of Wahua,

(1999).

Table (2). Physico-chemical properties of the prepared juice blends.

\begin{tabular}{|c|c|c|c|c|}
\hline \hline Parameter & Formula 1 & Formula 2 & Formula 3 & Formula 4 $^{\circ}$ \\
\hline \hline Moisture (\%) & $80.15 \pm 0.25^{\mathrm{b}}$ & $82.45 \pm 0.34^{\mathrm{a}}$ & $82.17 \pm 0.45^{\mathrm{a}}$ & $39.91 \pm 1.25^{\mathrm{c}}$ \\
\hline Ash (\%) & $0.34 \pm 0.09^{\mathrm{c}}$ & $0.29 \pm 0.01^{\mathrm{d}}$ & $0.56 \pm 0.03^{\mathrm{b}}$ & $2.96 \pm 1.22^{\mathrm{a}}$ \\
\hline Protein (\%) & $2.87 \pm 0.02^{\mathrm{c}}$ & $2.14 \pm 0.04^{\mathrm{d}}$ & $4.92 \pm 0.21^{\mathrm{b}}$ & $6.97 \pm 1.15^{\mathrm{a}}$ \\
\hline Fat (\%) & $1.32 \pm 0.02^{\mathrm{c}}$ & $1.19 \pm 0.04^{\mathrm{c}}$ & $6.11 \pm 0.02^{\mathrm{b}}$ & $27.20 \pm 0.02^{\mathrm{a}}$ \\
\hline Fiber (\%) & $0.90 \pm 0.65^{\mathrm{d}}$ & $2.16 \pm 0.52^{\mathrm{c}}$ & $2.13 \pm 0.33^{\mathrm{b}}$ & $5.83 \pm 1.83^{\mathrm{a}}$ \\
\hline Available carbohydrates & $15.32 \pm 0.31^{\mathrm{b}}$ & $13.93 \pm 0.42^{\mathrm{c}}$ & $6.24 \pm 0.17^{\mathrm{d}}$ & $22.96 \pm 0.33^{\mathrm{a}}$ \\
\hline pH & $4.63 \pm 0.18^{\mathrm{a}}$ & $4.41 \pm 0.36^{\mathrm{a}}$ & $4.15 \pm 0.42^{\mathrm{ab}}$ & $4.13 \pm .31^{\mathrm{b}}$ \\
\hline Acidity (\%) & $3.20 \pm 0.15^{\mathrm{b}}$ & $3.26 \pm 0.20^{\mathrm{b}}$ & $3.47 \pm 0.12^{\mathrm{a}}$ & $3.35 \pm 0.13^{\mathrm{ab}}$ \\
\hline TSS (\%) & $16.60 \pm 0.22^{\mathrm{c}}$ & $17.20 \pm 0.19^{\mathrm{b}}$ & $18.15 \pm 0.17^{\mathrm{ab}}$ & $18.70 \pm 0.11^{\mathrm{a}}$ \\
\hline TSS/ Acidity & $5.19 \pm 0.21^{\mathrm{b}}$ & $5.28 \pm 0.13^{\mathrm{ab}}$ & $5.23 \pm 0.11^{\mathrm{ab}}$ & $5.58 \pm 0.11^{\mathrm{a}}$ \\
\hline TS (\%) & $20.11 \pm 0.14^{\mathrm{a}}$ & $20.19 \pm 0.11^{\mathrm{a}}$ & $16.15 \pm 0.13^{\mathrm{b}}$ & $19.21 \pm 0.19^{\mathrm{a}}$ \\
\hline Apparent viscosity (cp) & $256.00 \pm 2.11^{\mathrm{b}}$ & $900.00 \pm 1.56^{\mathrm{a}}$ & $257.33 \pm 2.13^{\mathrm{b}}$ & $132.33 \pm 3.11^{\mathrm{c}}$ \\
\hline Vitamin C(mg/100gm) & $111.37 \pm 0.25^{\mathrm{a}}$ & $54.19 \pm 0.45^{\mathrm{c}}$ & $73.56 \pm 0.32^{\mathrm{b}}$ & $54.35 \pm 0.40^{\mathrm{c}}$ \\
\hline \hline
\end{tabular}

Average and standard Deviation of three replications Carbohydrates: calculated by difference Means within a row with different letters are significantly different at $\mathrm{P} \leq 0.05$.

On wet weight basis $\mathrm{N} \times 6.25$ factor was used as conversion factor

\section{RESULTS AND DISCUSSION Physico-chemical Properties}

The

physico-chemical characteristics of the prepared 4 juice blends Formula were summarized in Table (2). Total solids (TS) of all tested juice samples ranged between 16.15 - 20.19 Brix. These values were accepted with the standard TSS values of juice products which range between 10-20 Brix. The $\mathrm{pH}$ values of juice blends ranged between 4.13-4.63. Acidity ( $\%$ as citric acid) and TSS/acidity ratio of all juice samples ranged between 3.20 and $3.47 \%$ and 5.19 5.58 , respectively. These results are similar to that required for juice. The Brix value and $\mathrm{pH}$ recorded for different juice blends are within the recommended ranges for juice to hinder microbial growth and maintain keeping the juice quality as stated by Aina and Adesina (1999). Furthermore, all studied juice samples were accepted as a juice product where its viscosity ranged between 132.33 and $900 \mathrm{cp}$. Juices of different formulas were characterized by its high ascorbic acid and fiber contents which ranged between 54.19 - 111.37 $\mathrm{mg} / 100 \mathrm{~g})$ and $(0.90 \quad-5.83 \%)$, respectively. 


\section{Preparation of functional juice blends containing bioactive healthy compounds and antitumor effects}

\section{Total phenolic, total flavonoids and antioxidant activity of different juice blends}

Antioxidant compounds (i.e., phenolics compounds) in foods play a major role as a health protecting factor. Total phenols were measured as gallic acid equivalent (GAE) ug/100g of juice and total flavonoids were measured as catechen equivalent (ug CAT/100g). Both of them were evaluated in different juice blends. Table (3) presented that the higher total phenolic contents (571.67ug $\mathrm{GAE} / 100 \mathrm{~g}$ ) was found in formula 2 , followed by juice blend of formula 1 (258.33ug GAE/100g) then formula 3 (246.67ug GAE/100g) and the last one was formula 4 (151.67ug GAE/100g). On the other hand, the total flavonoids contents in juice blends were detected in sample with the formula 2 reached $26.67 \mathrm{ug}$ CAT/100g flowed by formula 1 was $22.65 \mathrm{ug}$
CAT/100g, while the formula 3 and formula 4 were 16.65 and $14.35 \mathrm{ug}$ CAT/100g, respectively.

Free radical scavenging (DPPH) is one of major the apparatuses for measuring the antioxidant activity. Table (3) shows the concentration of the compound required to scavenge the DPPH radical (ug/g). For the DPPH radical, juice prepared from formula 2 of carrot and sweet potato juice had the highest DPPH value $(686.84 \mathrm{ug} / \mathrm{g})$ followed by formula 1 of strawberry juice $(427.63 \mathrm{ug} / \mathrm{g})$, while the lowest DPPH was found in formula 4 of tiger nut juice $(331.75 \mathrm{ug} / \mathrm{g})$. The obtained results agreed with those given by Wolfe et al. (2003) who found that citrus and apple fibres have a good quality due to the occurrence of associated bioactive compounds, such as flavonoids, polyphenols and carotenes.

Table (3). The total phenol and flavonoid contents and antioxidant activity of 4 juice formula.

\begin{tabular}{|l|c|c|c|c|}
\hline \multicolumn{1}{|c|}{ Parameter } & Formula 1 & Formula 2 & Formula 3 & Formula 4 \\
\hline \hline Total phenols (ug GAE/100g) & 258.33 & 571.67 & 246.67 & 151.67 \\
\hline Total flavoinoids (ug CAT/100g) & 22.65 & 26.67 & 14.35 & 16.65 \\
\hline \multicolumn{7}{|c|}{ Antioxidant activity } \\
\hline DPPH (ug/g) & 427.63 & 686.84 & 406.32 & 331.75 \\
\hline
\end{tabular}

\section{Color Quality}

Color characteristics are one of the major parameters that affect the quality of the final product. Data in Table (4) represent color attributes of the four juices blends (formula 1 to formula 4). While lightness $\left(L^{*}\right)$ value was minimized in formula 3 of banana juice with peanut butter, where it decreased to 45.55. The highest redness $\left(a^{*}\right)$ value was found in formula 1 (22.26) of strawberry juice, followed by formula 2 and 3, where they recorded 14.52 and 12.84, respectively. The highest yellowness value $\left(b^{*}\right)$ was also found in formula 2 which composed of carrot and sweet potato juice (35.63) followed by formula 3 (24.12) and formula 4 of tiger nut juice (20.87). Table (4) showed also that, mixing different raw materials of different formula improved lightness $\left(L^{*}\right)$, redness $\left(a^{*}\right)$ and yellowness $\left(b^{*}\right)$ of all tested samples. This result could be due to the higher polyphenolic and flavonoid compounds and their antioxidant activities in raw materials as mentioned before. 
Table (4). Hunter color parameters of four formula juices.

\begin{tabular}{|l|c|c|c|c|}
\hline \hline \multicolumn{1}{|c|}{ Parameter } & Formula 1 & Formula 2 & Formula 3 & Formula 4 \\
\hline$L^{*}$ & 61.87 & 67.48 & 45.55 & 61.42 \\
\hline$a^{*}$ & 22.26 & 14.52 & 12.84 & 7.64 \\
\hline$b^{*}$ & 8.03 & 35.63 & 24.12 & 20.87 \\
\hline Saturation & 23.66 & 38.48 & 18.16 & 22.22 \\
\hline$a / b$ & 2.77 & 0.41 & 0.53 & 0.37 \\
\hline$\Delta E^{*}$ & 66.24 & 77.68 & 49.04 & 65.32 \\
\hline
\end{tabular}

$\left(L^{*}=92.46, a^{*}=-0.86, b^{*}=-0.16\right)$

$\Delta E=\sqrt{\Delta l 2}+\Delta a+\Delta b 2$

\section{Sensory Properties:}

Sensory Properties of juice has a great importance to evaluate consumer attitudes and their influence on food choice and acceptability. Thus, juice samples of diverse formulas were sensorial assessed and presented in Table (5). The obtained mean panel score and statistical analysis showed that, juice of formula 2 (carrot plus sweet potato) is characterized with its highest score in all the parameters (color, taste, odor, mouth feel, appearance and Overall acceptability), followed by formula 3 and formula 4 . The least accepted one was formula 1 of strawberry juice.

Table (5). Sensory properties of different juice formula.

\begin{tabular}{|l|c|c|c|c|}
\hline \multicolumn{1}{|c|}{ Parameter } & Formula 1 & Formula 2 & Formula 3 & Formula 4 \\
\hline Color (10) & $7.77 \pm 0.19^{\mathbf{c}}$ & $9.22 \pm 0.21^{\mathbf{a}}$ & $8.75 \pm 0.23^{\mathbf{b}}$ & $8.42 \pm 0.13^{\mathbf{b}}$ \\
\hline Taste (10) & $7.73 \pm 0.11^{\mathbf{c}}$ & $9.65 \pm 0.14^{\mathbf{a}}$ & $8.77 \pm 0.16^{\mathbf{b}}$ & $8.78 \pm 0.22^{\mathbf{b}}$ \\
\hline Odor (10) & $6.20 \pm 0.11^{\mathbf{c}}$ & $9.35 \pm 0.15^{\mathbf{a}}$ & $7.70 \pm 0.14^{\mathbf{b}}$ & $7.66 \pm 0.15^{\mathbf{b}}$ \\
\hline Mouth feel (10) & $6.62 \pm 0.12^{\mathbf{c}}$ & $8.79 \pm .19^{\mathbf{a}}$ & $7.39 \pm 0.13^{\mathbf{b}}$ & $7.79 \pm 0.21^{\mathbf{b}}$ \\
\hline Appearance (10) & $7.70 \pm 0.11^{\mathbf{c}}$ & $9.72 \pm 0.16^{\mathbf{a}}$ & $7.81 \pm 0.25^{\mathbf{b}}$ & $7.69 \pm 0.17^{\mathbf{b}}$ \\
\hline Overall acceptability (10) & $7.66 \pm 0.22^{\mathbf{c}}$ & $9.64 \pm 0.15^{\mathbf{a}}$ & $8.58 \pm 0.19^{\mathbf{b}}$ & $8.67 \pm 0.11^{\mathbf{b}}$ \\
\hline \hline
\end{tabular}

Average and standard Deviation of three replications

Means within a row with different letters are significantly different at $\mathrm{P} \leq 0.05$.

\section{In vitro Cytotoxicity assay}

The cytotoxicity of four juices formula on the viability of breast cancer (MCF-7), liver cancer (HEPG-2) and colon cancer (HCT116) cancer cell lines were evaluated using the sulphorhodamine Table (6). In vitro Cytotoxicity of four juices formula on breast cancer MCF-7 Cell lines ( $\mu \mathrm{g} / \mathrm{ml})$.

\begin{tabular}{|c|l|l|l|l|}
\hline & \multicolumn{5}{|c|}{ Viability NCF-7 } \\
\hline Concentration & \multicolumn{1}{|c|}{ Formula 1 } & Formula 2 & Formula 3 & Formula 4 \\
\hline 12.5 & 53.52 & 64.35 & 46.43 & 61.31 \\
\hline 25 & 37.36 & 44.51 & 31.99 & 42.45 \\
\hline 50 & 22.27 & 23.46 & 25.63 & 30.15 \\
\hline 100 & 12.54 & 15.21 & 13.17 & 12.78 \\
\hline $\mathrm{IC}_{50}$ & 19.15 & 20.16 & 22.12 & 18.14 \\
\hline
\end{tabular}

(SRB) bioassay. Cancer cell lines were exposed to different concentration of juices Formula $(12.5,25,50,100 \mu \mathrm{g} / \mathrm{ml})$. The results were summarized in Tables $(6,7 \& 8)$. 


\section{Preparation of functional juice blends containing bioactive healthy compounds and antitumor effects}

Activity of breast cancer $\mathrm{MCF}-7$ cell lines was expressed as the percentage of endurance cells exposed to juices Formula compared to the activity observed in the negative control for each concentration. From the mentioned results in Table (6), it was observed that the cytotoxicity of Four juices Formula on breast cancer (MCF-7), varies in a dosedependent manner. The minimum inhibiting effect was observed with $12.5 \mu \mathrm{g} / \mathrm{ml}$ concentration and there is steady increase in the inhibition effect against cell viability with the increase in the dose. The highest viability percent at the concentration of $100 \mu \mathrm{g} / \mathrm{ml}$ was shown $(18.78, \quad 15.21, \quad 13.17$ and $12.54 \%)$ for
Formula 2, Formula 3, Formula 4 and Formula 1, respectively. The maximum inhibition effects were revealed in IC50= $22.12 \mu \mathrm{g} / \mathrm{ml}$ for the Formula 3, while the lowest inhibition was in Formula 4. In this study the result of in vitro studies, were established that four juices formula inhibit cancer cell growth. While the previous reported results by Dahham et al. (2015), $\mathrm{Xu}$ et al. (2018) and Przybylska et al. (2007) found that formula 3(banana, carrot and sweet potato) and formula 2 (carrot and sweet potato) inhibited propagation of MCF-7 cells, and estrogen receptor unconstructive metastatic human breast cancer cells due to higher content of polyphenols.

Table (7). In vitro Cytotoxicity of four juices formula on liver cancer HePG-2 Cell lines $(\mu \mathrm{g} / \mathrm{ml})$.

\begin{tabular}{|c|l|l|l|l|}
\hline \multirow{2}{*}{ Concentration $\mu \mathrm{g} / \mathrm{ml}$} & \multicolumn{4}{|c|}{ Viability HePG-2 } \\
\cline { 2 - 5 } & Formula 1 & Formula 2 & Formula 3 & Formula 4 \\
\hline 12.5 & 64.32 & 65.37 & 54.27 & 63.21 \\
\hline 25 & 53.37 & 49.77 & 39.46 & 44.53 \\
\hline 50 & 25.41 & 22.13 & 20.91 & 23.87 \\
\hline 100 & 16.73 & 18.19 & 12.17 & 16.17 \\
\hline $\mathrm{IC}_{50}$ & 22.75 & 19.41 & 18.23 & 21.46 \\
\hline
\end{tabular}

Accomplish with different concentrations of four juices formula showed that a significant changeable cytotoxicity against liver cancer HEPG-2 cell lines compared to negative control cells Table (7). The capability of cancer cells was negatively associated to test extract concentration. Four juices Formula showed that the superior inhibition effect on cancer cell viability at all tested concentration could be due to its superior content of phenolic components that have anticancer effect on liver cancer cells during the negative effect on cancer cell. An analogous effect of cytotoxicity was marked at level of $(100 \mu \mathrm{g} / \mathrm{ml})$ as Viability percent was 18.19 for formula 2 and 16.73and 16.17 for formula 1 and formula 4 , respectively whilst formula 3 was $12.17 \%$.

Vilela et al. (2014), Achoribo et al. (2017) and Seeram (2006) proved that formula 1 (strawberry and banana) and formula 4 (tiger nut) inhibited propagation of liver cancer HePG-2 Cell, due to higher content of polyphenols. 


\section{Mahmoud A. Elwakeel}

Table (8). In vitro Cytotoxicity of four juices formula on colon cancer HCT 116 Cell lines $(\mu \mathrm{g} / \mathrm{ml})$.

\begin{tabular}{|c|l|l|l|l|}
\hline \multirow{2}{*}{ Concentration $\mu \mathrm{g} / \mathrm{ml}$} & \multicolumn{4}{|c|}{ Viability HCT 116 } \\
\cline { 2 - 5 } & Formula 1 & Formula 2 & Formula 3 & Formula 4 \\
\hline 12.5 & 67.53 & 72.52 & 76.71 & 62.31 \\
\hline 25 & 42.31 & 53.27 & 46.83 & 36.57 \\
\hline 50 & 29.74 & 26.46 & 26.42 & 22.16 \\
\hline 100 & 16.85 & 14.35 & 12.41 & 14.65 \\
\hline $\mathrm{IC}_{50}$ & 23.15 & 25.80 & 22.19 & 20.12 \\
\hline
\end{tabular}

Handling of colon cancer by means of special concentrations of four juices formula showed that a considerably variable cytotoxicity against colon cancer cells compared to negative delivery cells. The lowest inhibition concentration was $12.5 \mu \mathrm{g} / \mathrm{ml}$ and there was a regular increase in the inhibition effect against cell viability as the concentration increases, which is evidently illustrated in Table (8). The cytotoxicity of formulas 1,4 and 2 of $(100 \mu \mathrm{g} / \mathrm{ml})$ leads to Viability percentage of $16.85 \%, 14.65 \%$ and 14.35 respectively, whereas it was $12.41 \%$ in formula 3 , on colon cancer HCT 116 Cell lines.

For the majority part energetic concentration of formula 2 in reducing activity of cancer cells (HCT 116 Cells) IC $50=25.80 \mu \mathrm{g} / \mathrm{ml}$ for pomegranate peels $\mathrm{EtOH}$ extract followed by $23.15 \mu \mathrm{g} / \mathrm{ml}$ for formula 1 , respectively.

In this study formula 2 (carrot and sweet potato) and formula 1 (strawbery and banana) have been shown to inhibit cell growth in colon cancer cell lines. The present findings were in agreement with results obtained by Seeram et al. (2006), Dahham et al. (2015) and Zaini et al. (2011).

From the previous results it could be concluded that, all tested formulas characterized with its chemical contents and bioactive healthy compounds. Moreover, all formula were accepted through sensory evaluation parameters. Therefore, it could be recommended to prepare such juice blends as a nutritious healthy functional juice.
Achoribo, E.S. and Ong, M.T. (2017). Tiger nut (Cyperus esculentus): Source of natural anticancer drug? Brief review of existing literature. Euro Mediterranean Biomedical J., 12(19):091-094. 10.3269/19705492.2017.12.19

Aina, J.O. and Adesina, A.A. (1999). Suitability of frozen indigenous tropical fruits for jam processing. Advances in Food Sci., 2: 15 - 18.

Ajila, C.M.; Bhat, S.G. and Rao, P.U.J.S. (2007). Valuable components of raw and ripe peels from two Indian mango varieties. Food Chem.,102:1006-11. https://doi.org/10.1016/j. foodchem.2006.06.036

Ali, B.H.; Blunden, G.; Tanira M.O. and Nemmar, A. (2008). Some phytochemical, pharmacological and toxicological properties of ginger (Zingiber officinale Roscoe): A review of recent research. Food Chem. Toxicol., 46(2): 409-420.

AOAC (1995). Official Methods of Analysis of the Association of Official Analytical Chemists. $15^{\text {th }}$ Edn., Association of Official Analytical Chemists Inc., Arlington, Virginia, USA.

Belščak-Cvitanović, A.; Komes, D.; Benković, M.; Karlović, S.; Hečimović, I.and Ježek, D. (2012). Innovative formulations of chocolates enriched with plant polyphenols from Rubus idaeus L. leaves and characterization of their 


\section{Preparation of functional juice blends containing bioactive healthy compounds and antitumor effects}

physical, bioactive and sensory properties. Food Res. Int., 48(2): 820-830.

Buve, C.; Neckebroeck, B.; Haenen, A.; Kebede, B.; Hendrickx, M.; Grauwet, T., and Van Loey, A. (2018). Combining untargeted, targeted and sensory data to investigate the impact of storage on food volatiles: A case study on strawberry juice. Food Res. Int., 113: 382-391.

Chow, J. (2002). Probiotics and prebiotics: a brief overview. J. Ren. Nutr., 12:76-86.

Dahham, S.S.; Mohamad, T.A.; Tabana, Y.M. and Majid, A.M. (2015). Antioxidant activities and anticancer screening of extracts from banana fruit (Musa sapientum). Academia J. Cancer Res., 8:28-34. doi: 10.5829/idosi.ajcr.2015.8.2.95162

Day, L.; Xu, M.; Øiseth, S. K.; Hemar, Y., and Lundin, L. (2010). Control of morphological and rheological properties of carrot cell wall particle dispersions through processing. Food and Bioprocess Technol., 3: 928-934.

De Carvalho, J.M; Maia, G.A. and De Figueredo, R.W. (2007). Development of a blended nonalcoholic beverage composed of coconut water and cashew apple juice containing caffeine. J. Food Qual., 30: 664-681.

Deka, B.C. and Sethi, V. (2001). Preparation of mixed fruit juice spiced RTS beverages. Ind. Fd. Packer, 42(3): 58-61.

Di Giacomo, G. and Taglieri, L. (2009). A new high-yield process for the industrial production of carrot juice. Food and Bioprocess Technol., 2: 441-446.

Filotheou, A. ; Nanou, K. ; Papaioannou, E. ; Roukas,T. ; Kotzekidou, P. and Liakopoulou-Kyriakides,
M. (2012). Application of response surface methodology to improve carotene production from synthetic medium by Blakeslea trispora in Submerged Fermentation. Food and Bioprocess Technol., 5:11891196

Fleischauer, A.T.; Simonsen, N. and Arab, L. (2003). Antioxidant supplements and risk of breast cancer recurrence and breast cancer-related mortality among postmenopausal women. Nutr. Cancer., 46: 15-22. https://doi.org/10.1207/s15327914 nc4601_02

Gambo, A. and Da'u, A. (2014). Tiger nut (Cyperus esculentus): composition, products, uses and health benefits a review. Bayero J. Pure and Appl. Sci., 7(1): $56-61$.

Grzegorczyk, I.; Matkowski,A. and Wysokinska,H. (2007). Antioxidant activity of extracts from in vitro cultures of Salvia officinalis L. Food Chem., 104: 536-541.

Hădărugă, V.N.; Traşcă, T.; Jianu, C. and Jianu, I. (2009). Researches regarding the Antioxidant capacity of some fruits vinegar. $\mathbf{J}$. Agroalimentary Processes and Technologies, 15(4): 506-510.

Holmes, B. (2013). Go Bananas. New Scientist, 218:39-41.

Hussein, A.M.S. and Shedeed,N.A. (2011). Production of good quality drinks from some Egyptian berry fruits varieties. Model. Meas. Control, 72: 26-37.

Ibarz, A.; Gonzalez, C. and Esplugas S. (1994). Rheology of clarified fruit juices. III: Orange juices. J. Food Eng., 21: 485-494.

Kulkarni, S. G.; Vijayanand, P. and Shubha, L. (2010). Effect of processing of dates into date juice concentrate and appraisal of its quality characteristics. J. Food Sci. Technol., 47(2):157-161 


\section{Mahmoud A. Elwakeel}

Kurosawa,Tt.; Itoh, F.; Nozaki, A.; Nakano, Y.; Katsuda, S.-I.; Osakabe, N.; Tubone, H.; Kondo, K. and Itakura, H. (2005). Suppressive effect of cocoa powder on atherosclerosis in Kurosawa and Kusanagi hypercholesterolemic rabbits. J. Atheroscler. Thromb., 12:20-28.

Lamaison, J.L.; Petitjen-Freytet,C. and Carnat,A. (1990). Rosmarinic acid, total hydroxyacinnamic derivative contents and antioxidant activity of medicinal Apiaceae, Borraginaceae and Lamiaceae. Ann. . Pharma. Franc., 48: 103-108.

Matthaus, B. (2002). Antioxidant activity of extracts obtained from residues of different oilseeds. J. Agric. Food Chem., 50: 3444-3452.

Murphy, C.T.; McCarroll, S.A.; Bargmann, C.I.; Fraser, A.; Kamath, R.S.; Ahringer J.; Li, H; and Kenyon, C. (2003). Genes that act downstream of DAF-16 to influence the life span of Caenorhabditis elegans. Nature, 424:277-283. doi:10.1038/nature 01789

Onyeagba, R.A.; Ugbogu, O.C.; Okeke, C.U.and Iroakasi O. (2004). Studies on the antimicrobial effects of garlic (Allium sativum Linn), ginger (Zingiber officinale Roscoe) and lime (Citrus aurantifolia Linn). Afr. J. Biotechnol; 3(10): 552-554.

Przybylska, K.; Bennett, R.N.; Kromer, K. and Gee, J.M. (2007). Assessment of the antiproliferative activity of carrot and apple extracts. Polish J. Food Nut. Sci., 57:307-314

Sapers, G.M. and F.W. Douglas (1987). Measurement of enzymatic browning at cut surfaces and in juice of raw apple and pear fruits. J. Food Sci., 52: 1258-1285.

Seeram, N.P.; Adams, L.S.; Zhang, Y. and Lee, R.S. (2006). Blackberry, black raspberry, blueberry, cranberry, red raspberry, and strawberry extracts inhibit growth and stimulate apoptosis of human cancer cells in vitro. J. Agric. Food Chem., 54: 9329-9339.

Skehan, P.; Storeng, R.; Scudiero, D.; Monks, A.; McMahon, J. and Vistica, D. (1990). New Colorimetric Cytotoxicity Assay for anticancer drug screening. JNCI J. Nat. Cancer Inst., 82(13): 11071112.

Sultana, B.; Hussain, Z.; Asif, M. and Munir, A. (2012). Investigation on the antioxidant activity of leaves, peels, stems bark, and kernel of mango (Mangifera indica L.) J. Food Sci.,77(8): 849- 852. https://doi.org/10.1111/j.1750-3841. 2012.02807.x

Teuscher, E. (2003). Zimt. In: Gewurzdrogen. pp. 423-429. Wissenschaftliche Verlagsgesellschaft, Stuttgart, Germany.

Tomaru, M.; Takano, H.; Osakabe, N.; Yasuda, A.; Inouse, K. I.; Yangisawa, R., Ohwatari, T. and Uematsu, H. (2007). Dietary supplementation with cacao liquor proanthocyanins prevents elevation of blood glucose levels in diabetic obese mice. Nutrition, 23: 351355.

Vilela, C.; Santos, S.A.; Villaverde, J.J.; Oliveira, L.; Nunes, A. and Cordeiro N. (2014). Lipophilic phytochemicals from banana fruits of several Musa Species. Food Chem. (2014) 162:247-52. doi: 10.1016/j.foodchem.2014.04.050

Wahua, T.A.T. (1999). Applied statistics for scientific studies. Afrika-Link Books, Nigeria; pp. 250-287, https://doi.org/10.12691/ajfst-4-23.

White, J.W. (1979). Composition of honey. In: Crane E, editor. Honey: A Compre Survey. London: Heinemann: 157-192. 


\section{Preparation of functional juice blends containing bioactive healthy compounds and antitumor effects}

Wolfe, K.; Wu, X. and Liu, X. (2003). Antioxidant activity of apple peels. Food Chem., 51: 609-614.

Wootton-Beard, P.C. and Ryan, L. (2011). Improving public health? The role of antioxidant-rich fruit and vegetable beverages. Food Res. Int. 44(10):3135-3148.

https://doi.org/10.1016/i.foodres.201 1.09 .015

Xu, H.S.; Li, Y.F.; Han, B.; Li, Z.X.; Jiang, P.; Zhang, J.; Ma, W.Y.; Zhou, D.Q.; Li, X.G. and Ye, X.L. (2018). Anti-breast- cancer activity exerted by $\beta$ sitosterol-d-glucoside from sweet potato via up regulation of microRNA-10a and via the PI3K-Akt signaling pathway. J. Agric. Food Chem., 66 (37): 9704-9718.

Zaini, R.; Clench, M.R. and Maitre, C.L. (2011). Bioactive chemicals from carrot (Daucus carota) juice extracts for the treatment of leukemia. J. Med. Food, 14:13031312. http://dx.doi.org/10.1089/jmf .2010 .0284

\section{تحضير خلطات عصير وظيفية تحتوي على مركبات صحية نشطة بيولوجيًا وتأثيرات مضادة للأورام}

$$
\text { قسم علوم الاغذية ، كلية الزر اعة ، جامعة بني سويف ، لوكيل بني سويف ، بني سويف } 62511 \text { ، مصر }
$$

المستخلص

تعتبر عصائر الفاكهة من المشروبات الصحية ، حيث تحتوي على فيتامينات ومعادن ومضادات الأكسدة التي

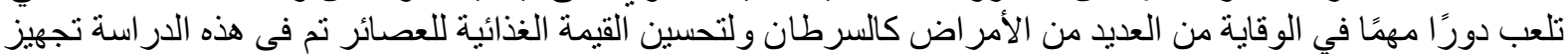

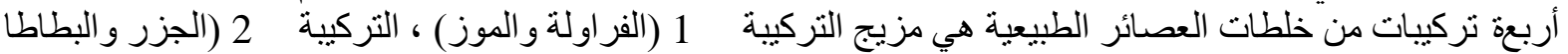
الحلوة) التركيبة 3 (الموز و الجزر و البطاطا الحلوة) والتركيبة 4 و (حب العزيز ). تم تقييم الخواص الفئية الفيزيائية و الكيميائية و الحسية لخلطات العصائر المحضرة و تم تقييم إجمالي الفينو لات ، و إجمالي مركبات الفلافونويد و النشاط المبات المضاد للأكسدة

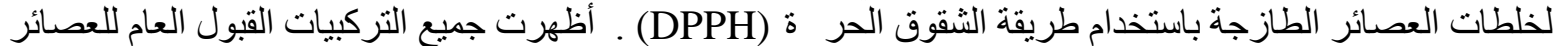
المخلوطة مما وان لها إمكانية تحضير تتميز بخصائص حسية وغذائية جيدة. كما أتضح لمكانية استخدام عصائر الفاكهة

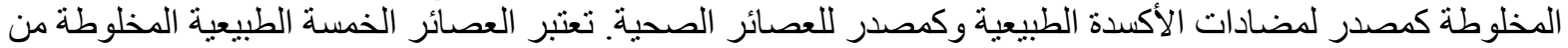

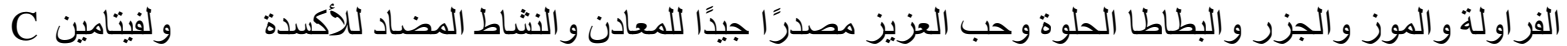

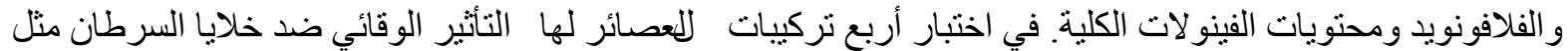

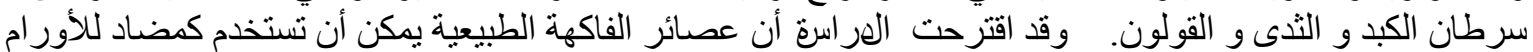
لاحتو ائها على بعض المركبات النشطة بيولوجيًا مثل الفينول و الفلافونويد ذات الأنشطة المضادة للأكسدة . 